\title{
Usage ICT Application for Bundling Products: Strategic Digital Marketing in Facing the 4.0 Technology
}

\author{
John Tampil Purba ${ }^{1}$, Hery $^{2}$, Putra C Purba ${ }^{3}$ \\ \{john.purba@uph.edu ${ }^{1}$, hery.fik@uph.edu ${ }^{2}$ \} \\ Universitas Pelita Harapan, Jl. MH. Thamrin Boulevard 1100, Karawaci, Tangerang, Banten, \\ Indonesia $^{12}$, Independent ICT Consultant in Jakarta, Indonesia ${ }^{3}$
}

\begin{abstract}
The use of ICT applications in the era technology of 4.0 for Product bundling due to retain customers and to increase the number of subscribers currently used by entrepreneurs as the strategy to maintain their market because it can increase the sales and profits both in terms of financial and brand products. This study using data mining and Front end FP-Growth algorithm as an alternative used to determine the frequent item set in a set of data. From the results found that the value of support for $20 \%$ and confidence of $60 \%$ as optimal parameters for FP-Growth algorithm to produce more bundling and performance faster than apriori algorithm. Thus the use of this application is very important and useful for use by retail business as the tools of marketing strategy with bundling productsThe abstract needs to summarize the content of the paper.
\end{abstract}

Keywords: ICT application, bundling products, strategy, digital world.

\section{Introduction}

The impact of globalization economy and digital technology of 4.0 era makes the world seems boardeless. Any happens in one big country can be influenced many countries over the world. Business Companies over the countries depend on each other; they used internets, telecommunications and other technology facilities in transaction activities [1]. So the development of ICT provides better services to connect the customers, suppliers, and faster respond to the customers and client's needs. In the opinion of [2] Richard, Coltman, and Keating] Information technology-based innovation involves considerable risk that requires insight and foresight. Yet, our understanding of how managers develop the insight to support new breakthrough applications is limited and remains obscured by high levels of technical and market uncertainty. Purba [3] also recommended; in sustaining their organization services in the same time the companies, organizations, and goverments accomodate that change. Due to the situation; need the decision to invest in the IS/IT for the sake service strategy requires to meet organisational goal and competitive needs. In Indonesia case practically has been done in some evidence, but according to researchers there is no one paper by combining IT application and using regression analysis the market observation on this matter.

The research of Venkatesh and Mahajan [4] bundling, the strategy of marketing products in particular combinations, is growing in significance given the boom in high technology and eCommerce. Using the application of marketing information systems are based on computer

ICCSET 2018, October 25-26, Kudus, Indonesia

Copyright (C) 2018 EAI

DOI 10.4108/eai.24-10-2018.2280543 
systems which work in conjunction with another of functional information application to support the firm's management in solving problems that relate to marketing the firm's products [5]. They have been used to collect information for marketing actions, analyses and present them to the marketing manager for making effective decisions. Marketing Information Systems are help systems that can be used to product strategic, operational and tactical decisions for the marketing management [6]. By this research paper, will give contribution the readers how application in bundling marketing strategy powerful for the firm.

\section{Literature Review}

Electronic commerce (EC) in 4.0 technology era are popular topics in the number of mass media and in informatics circles as well and the impact is most visible in the areas of financial services and retailing. With IT can remote payments and electronic checking, online trading of stocks, bonds and related financial instruments, online banking, and online retailing (e-tailing) Gunasekarana, et al [6]. As witnessed today about true revolution with the growth of the Internet and Internet use. The tools and techniques to enable trading over the Internet are becoming mature, and EC is growing very rapidly. Back in 1997 the global EC market was estimated at $\$ 10$ billion, but is predicted to rise to $\$ 200-300$ billion, by 2002 [6],[7]. Electronic Data Interchange (EDI), the business-to-business exchange of data and e-mail and fax and their use as media for reaching prospects and established customers [8]. For the big and large transaction the application must use the data mining to manage the activities of the business running.

The definition of data mining as described by Deming [9] Data mining is the process of obtaining useful information from large databases where it is used to extract new information derived from large data chunks that aid in decision making. Zent [10] data mining is described as a process of discovering or extracting interesting knowledge from large amounts of data stored in multiple data sources such as file systems, databases, data warehouses etc. In application to run the product bundling the researchers use the [11] FP-Growth is an alternative algorithm that can be used to determine the frequent item set in a data set. FPGrowth uses a different approach from the a priori paradigm.

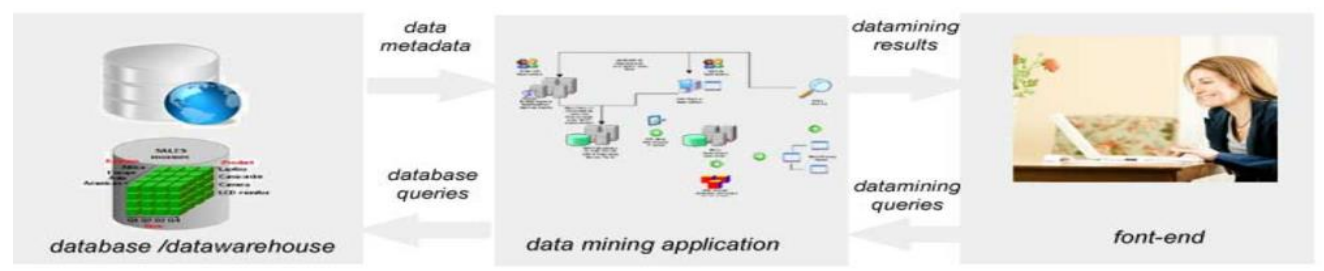

Fig. 1. The Data Mining Architecture [Zen T].

For strategic marketing the usage of applications system is helpful to increase the distribution of channel as stated by Purba [12] IT innovation becoming one of the compulsory tools in any enterprises, business companies and other organizations in running the activities within in the new ways, where the results are more effective and efficient. For industries 
where information itself a product, we would expect to see an increasing number of IT applications that pertain directly to the product. Such differences, if in fact true, should be reflected in the events discussed by the CEO in the annual report. In line to Purba's statement, [13] Chung et al, bundling is a commonly seen marketing strategy. The major purposes of the bundling strategy are to extend the firm's monopoly power in one market to another market, to adopt price discrimination, to deter a potential competitor from entry, and to perform strategic alliances. This is named the so-called leverage theory. Stremersch and Tellis [14] described that bundling is the sale of two or more separate products in a package. This strategy is pervasive in markets today in one form or another. ICT usage in managing companies and other organizations become a strategic choice of innovation to achieve competitive advantage nowadays. According to Kamaludin \& Purba [15] the ICT and its applications become main tool to implement corporate sustainability, so the readiness and acceptance of the new technology contributing to organizational effectiveness in running the companies and or organizations. The strategic fight to the competitors the bundling product usually used as assumed inelastic demand and Bertrand competition and find that the bundling firm reduces the competing product's price and takes the market share. In this case, bundling has a strategic foreclosure effect, making the competitor's profit drop as stated by Whinston [16].

The domain strategy marketing of bundling product also use to get better price as Mulhem and Leone [17] introduced the concept of implicit price bundling as the pricing strategy whereby the price of a product is based on the multitude of price effects that are present across products without providing consumers with an explicit joint price. The purpose of bundling itself also described by Stremersch \& Tellis [14] in their articles reported that the Economists have focused mainly on the optimality of bundling for monopolists [18] Adams and Yellen 1976; [19] Burstein I960; [20] Carbajo, [21]Long 1984; [22] McAfee, McMillan, and Whinston 1989; [23] Pierce and Winter 1996; [24] Schmalensee 1982, 1984. They also stated about the welfare implications of bundling [25] (Dansby and Conrad 1984; [26] Martin 1999; [27] Salinger 1995. From the above literatures, shown that bundling products strategy have motivated the customers or buyers, then if they are support by e-commerce application will give significant and relevant contributions to upgrade the larger sales of product.

\section{Methodology}

Research in the field of computer science, information systems and information technology, often uses experimental design. It also needs a scientific approach to generate new knowledge. Referring to Hasibuan [28] in computer science research, information systems, and IT there are two approaches of science and engineering. In line to that, Numaker [29] in conducting IS research that incorporated theory building, systems development, experimentation; observation is proposed by. The researchers consumed time for a few months to collect data from the field in the area of Bandung West Java by experience of observation at Jakarta before. The retailers' companies usually give information in front of their supermarkets which of the products are bundling, also distributed questionnaires to a number of respondents but only 167 questionnaires back to researchers. Data collection for this research use the sampling the data, the technique used is nonprobability sampling from the field. The main purpose of packaging the product or product bundling is to bundling the product type snack, beer, and cigarettes. In this paper the researchers' observation going to the 
field such as supermarkets, Indomart, Alfamart and others related to see the market phenomena of the buyers and customers' behavior. Then, did the scratch paper for business analysis and start building, coding, testing and final acceptance test of the system application of the bundling products.

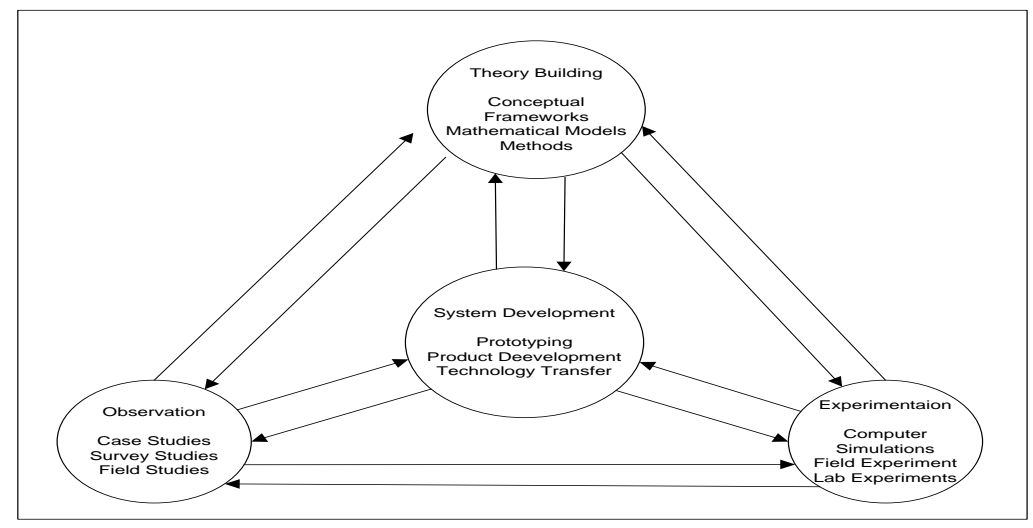

Fig. 2. A Multi methodological Approach to Is Research.

\section{$4 \quad$ Findings and discussion}

The aim of this project is to see whether the FP-Growth better than the existing one for higher information technology in increasing the sales especially for them who running the retail business/companies. Here below the will describe how the systems works as shown figure 3 below:

Data Sampling $\rightarrow$ Frequent Products $\rightarrow$ Frequent Item $\rightarrow$ Data Cleaning with Support Threshold $\rightarrow$ Frequency of Occurence order by descending $\rightarrow$ Grading Value Priority $\rightarrow$ filtering products base on priority value $\rightarrow$ FP-Tree construction $\rightarrow$ Conditional Pattern Base $\rightarrow$ Conditional FP-Tree (FP-Growth) $\rightarrow$ Rules Generation $\rightarrow$ rules with minimum support $\&$ confidende $\rightarrow$ result of product bundling $\&$ lift measure

Fig. 3. Flow Chart of System works.

FP-Growth algorithm is used for finding the patterns of product bundling from sales transaction data by recursively calling the method with every sales record data, the coding of the FP-Growth can be seen from the display of pseudocode of the algorithm showed in Figure 4. 


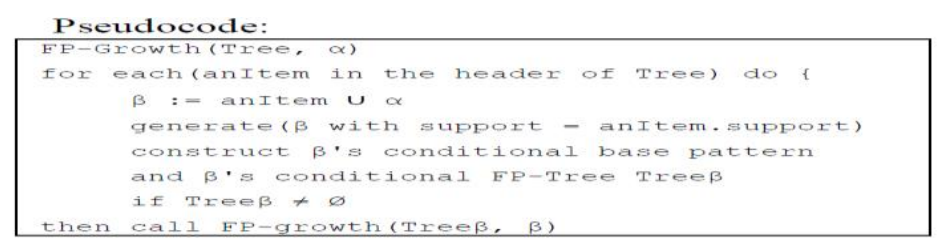

Fig.4. Pseudocode FP tree, Purba [30].

The flow of the system showed in Figure 4 by figuring 3 main phase of that consist of data sampling, data preprocessing, main processing, and result evaluation. Figure 4 shows, fields that important for searching the product bundling is NoBill, Product, and Qty within 1000 data. The main purpose of FP-Growth is building the logic-tree based on sales transaction data and scanning every product in every transaction to build the branches of related product where customers frequently buy the products simultaniuosly. As displayed in the figure the numbers on the left express the product code which is defined in preprocessing phase, where the other side express frequency of that product bought simultaniuosly with parent branches.

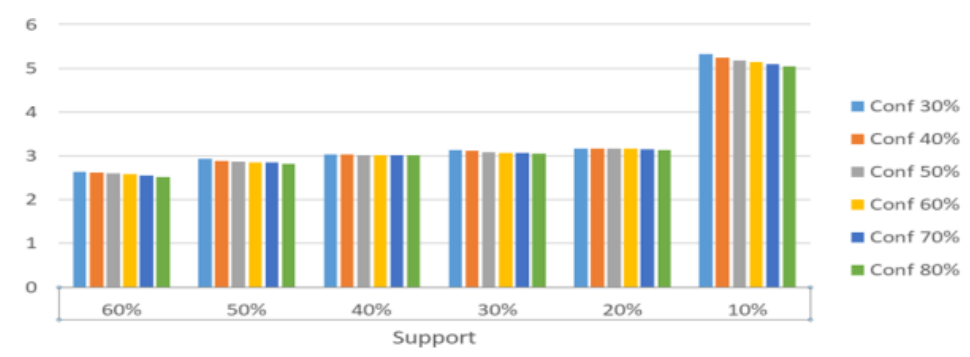

Fig. 5. Chart between Support and Confidence Value toward time Execution, Purba [30].

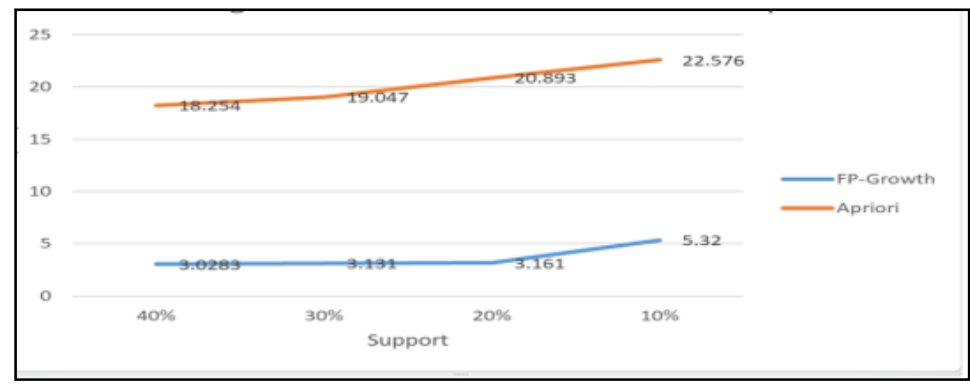

Fig. 6. Comparison of time execution FP-Growth and Apriori. Purba, CP [30].

Having executed the implementation of FP-Growth algorithm as described in table 2, the next step is running again for the speed of searching product bundling across all sales of the transaction data. Here the resulting of FP-Growth beat is six times faster comparing to Apriori. 
Figure 9 below, shows that the FP-Growth processing is in the level of $5.32 \mathrm{~ms}$ compared to Apriori by $22.576 \mathrm{~ms}$ by processing the same allocation of 1000 data.

For further analysis of the data findings which collected, first tested the validity and reliability. This test aims to determine whether the data obtained from the questionnaires are in the level of validity and reliability can be trusted and relied on. The test using the Pearson Correlation for testing the validity and reliability by calculating the Cronbach Alpha coefficients.

Table 1. Validity and Reliability test.

\begin{tabular}{|c|c|c|c|c|}
\hline \multicolumn{5}{|c|}{ Validity and Reliability test for Expected value data } \\
\hline Var. IT Apps IA1 & IA2 & IA3 & IA4 & IA5 \\
\hline $.644(* *)$ & $.530(* *)$ & $.468(* *)$ & $.457(* *)$ & $.553(* *)$ \\
\hline \multicolumn{5}{|c|}{ Reliability Alpha $=.745$} \\
\hline Var. Bund Pro BP1 & BP2 & BP3 & BP4 & BP5 \\
\hline $.388(* *)$ & $.504(* *)$ & $.395(* *)$ & $.507(* *)$ & $.490(* *)$ \\
\hline \multicolumn{5}{|c|}{ Reliability Alpha = .671 } \\
\hline Var. Digital & D2 & D3 & D4 & \\
\hline .333 & .571 & .543 & .463 & \\
\hline \multicolumn{5}{|c|}{ Reliability Alpha $=.706$} \\
\hline
\end{tabular}

**Correlation is significant at the 0.01 level (2-tailed). * Correlation is significant at the 0.05 level (2-tailed).

In table -2 , it is shown that the Pearson correlation value for each variable is significant at the level of 0.01 , so the data obtained from the questionnaires is valid. For Cronbach values for each group of questionnaires where the questionnaires grouped in to 3 variable components, value of Cronbach also found greater than 0.6 , so it can be said the result of the questionnaire is reliable.

\subsection{Multiple Regression Analysis}

Table 2. Coefficients of determination

\begin{tabular}{cccccc}
\hline Model & $\mathrm{R}$ & $\mathrm{R}$ Square & $\begin{array}{c}\text { Adjusted R } \\
\text { Square }\end{array}$ & $\begin{array}{c}\text { Std. Error of the } \\
\text { Estimate }\end{array}$ & Durbin-Watson \\
\hline 1 & $.387^{\mathrm{a}}$ & .150 & .139 & 1.86193 & 1.148 \\
\hline
\end{tabular}

Predictors: (Constant), BP, IA. b. Dependent Variable: Digital Marketing 
From table Coefficient of determination R-squared is a goodness-of-fit measure for linear regression models ICT application (IA) and Bundling Product (BP) toward Digital Marketing with R2 0.150. This means that the IA and BP variables explain the change in Digital Marketing (Y) variable by $15 \%$ while the remaining $85 \%$ is explained by other factors outside the model.

Table 3. Multiple Regression Coefficients ${ }^{\mathrm{a}}$

\begin{tabular}{|c|c|c|c|c|c|c|}
\hline & \multirow[t]{2}{*}{ Model } & \multicolumn{2}{|c|}{ Unstandardized Coefficients } & $\begin{array}{l}\text { Standardized } \\
\text { Coefficients }\end{array}$ & \multirow[t]{2}{*}{$\mathrm{t}$} & \multirow[t]{2}{*}{ Sig. } \\
\hline & & $\mathrm{B}$ & Std. Error & Beta & & \\
\hline \multirow[t]{3}{*}{1} & (Constant) & 7.674 & 1.206 & & 6.362 & .000 \\
\hline & IA & .157 & .048 & .252 & 3.276 & .001 \\
\hline & $\mathrm{BP}$ & .187 & .066 & .219 & 2.847 & .005 \\
\hline
\end{tabular}

Dependent Variable: Digital Marketing World

Mathematical regression equation formula is $\mathrm{Y}=\beta x+b 1 x 1+b 2 x 2+\varepsilon$, then translated will be; $\mathrm{Y}=\beta 7.674+0.157$ ict_application +0.187 bundling_product $+\varepsilon$

1) Regression constant value of 7.674 indicates that in ICT Application (IA) 0.157 and Bundling Product (BP) with constant condition or $\mathrm{X}=0$, then the Digital Marketing (Y) 7.674 .

2) ICT Application (IA) regression coefficient is 0.157 has a positive effect on Digital Marketing (Y). This means that if ICT Application (IA) is better while assuming another variable is constant, then it can increase the sales through digital marketing (Y)

3) Bundling Product (BP) with regression coefficient value 0.187 has a positive effect on customer satisfaction (Y). It means the use of digital marketing will increase the sales of product bundling (Y) 0.187 .

The above regression coefficients result shows that Bundling Product (BP) has greater influence than e- ICT application (X1) for Digital Marketing (Y), based on regression coefficient value of 0.187 (unstandardized coefficients) and Beta value of 0.219 (standardized coefficients) with a significant of 0.005 .

\section{Conclusion and recommendation} follows:

Having discussed and analiyzed the above findings and results, the conclusion derived as

1) The support value is $20 \%$ of the total data Transaction is quite optimal in getting effective bundling by considering algorithm execution time. The support value affects the execution time of the FP-Growth algorithm and the resulting bundling or number of rules. The smaller the support value, the longer it will take to search the pattern.

2) The FP-Tree algorithm can be up to six times faster at a support value of $40 \%$ and four times faster at a support value of $10 \%$ compared to the Apriori algorithm.

3) From the finding and results by using the Multiple regression analysis that usage of ICT application and Bundling product have a strong effect on Digital Marketing activities. 
4) This application is already proven to be used for the companies which running the retail business by following the proposed strategy management by using digital marketing as the following:

5) Intensive Strategy: by implementing the Product development strategy and Market Penetration strategy

6) Diversification Strategy; by using the Horizontal and Concentric diversification.

7) Michael Porter Generic Strategy: by implementing ICT application with Cost Leadership, Differentiation by using digital technology and Focus on product bundling.

In research the researchers looked that the bundling and pricing usually used as the empirical approaches to actually design or price product bundles. However, in order to gain more customers and buyers herewith, we propose using this new technology application as a marketing strategy to compete in today's digital era.

\section{References}

[1] J. T. Purba, "Service Performance ICT Train New Technologies Towards Orgazizations : Case Study Asindo Informatika," in . Seminar Nasional dan Call Paper "Business in Society: Towards Asian Era, FEB UNS, Surakarta 18-19 Maret 2014, 2014.

[2] P. J. Richard, T. R. Coltman, and B. W. Keating, "Designing IS service strategy: An information acceleration approach,” Eur. J. Inf. Syst., vol. 21, no. 1, pp. 87-98, 2012.

[3] J. Tampil Purba and R. Panday, "Innovation strategy services delivery: An empirical case study of academic information systems in higher education institution," in Communications in Computer and Information Science, 2015, vol. 516, pp. 514-525.

[4] R. Venkatesh and V. Mahajan, "The design and pricing of bundles: a review of normative guidelines and practical approaches," Handb. pricing Res. Mark., vol. 31, no. 1, pp. 232-257, 2009.

[5] J. T. Purba, "Service Management Strategy by Implementing Academic Information Systems in Indonesia Higher Education," in Proceeding. Presented in the International Seminar 11th Insyma, Batu, Malang Indonesia. March, 2014.

[6] A. Gunasekaran, H. B. Marri, R. E. McGaughey, and M. D. Nebhwani, "E-commerce and its impact on operations management," Int. J. Prod. Econ., vol. 75, no. 1-2, pp. 185-197, 2002.

[7] I. F. Morphett, BT technology journal. 1999.

[8] E. Purba, C.P \& Siswanto, "Implementasi Algoritma FP-Growth untuk Market Basket Analysis dalam Menentukan Product Bundling." 2017.

[9] W. Edwards-Deming, "Sample_design_in_business_research." 1990.

[10] ZenTut, "Data Mining Arhitecture. Introduction to Data Mining Architecture." 2017.

[11] R. Agrawal and R. Srikant, "Fast \{Algorithms \} for \{Mining\} Association $\{$ Rules in \{Large\} \{Databases\}," in Proceedings of the 20th \{International\} \{Conference\} on \{Very\} \{Large\} \{Data\} \{Bases\}, 1994, pp. 487-499.

[12] J. . Purba, "Applied ICT Innovation Services of Academic Information System: Strategy for Higher Educational Management," in International Conference of Organizational Innovation (ICOI), 2015.

[13] H. L. Chung, Y. S. Lin, and J. L. Hu, "Bundling strategy and product differentiation," J. Econ. Zeitschrift fur Natl., vol. 108, no. 3, pp. 207-229, 2013.

[14] S. Stremersch and G. J. Tellis, "Strategic Bundling of Products and Prices: A New Synthesis for Marketing," J. Mark., vol. 66, no. 1, pp. 55-72, 2002.

[15] K. Kamaludin and J. T. Purba, "Strategic Management Banking Technology Readiness Analysis in Facing Challenges and Opportunities," in Proceedings of the International Conference on 
Economics and Banking 2015, 2015.

[16] W. M. D. 'Tying., "Foreclosure, and Exclusion." American Economic Review," American Economic Review, vol. 80, no. 4, pp. 837-59, 1990.

[17] F. J. Mulhern and R. P. Leone, "Implicit Price Bundling of Retail Products: A Multiproduct Approach to Maximizing Store Profitability," J. Mark., vol. 55, no. 4, p. 63, 1991.

[18] W. J. Adams and J. L. Yellen, "Commodity Bundling and the Burden of Monopoly," $Q . J$. Econ., vol. 90, no. 3, p. 475, 1976.

[19] B. M.L., "'The Economics of Tie-In Sales." Review of Economics and Statistics," 1960.

[20] J. Carbajo, D. de Meza, and D. J. Seidmann, "A Strategic Motivation for Commodity Bundling," J. Ind. Econ., vol. 38, no. 3, p. 283, 1990.

[21] J. Long. J. B., “Comments on 'Gaussian Demand and Commodity Bundling," Joumai Bus., vol. 57, no. 1, pp. S235-S246, 1984.

[22] R. P. McAfee, J. McMillan, and M. D. Whinston, "Multiproduct Monopoly, Commodity Bundling, and Correlation of Values," Q. J. Econ., vol. 104, no. 2, p. 371, 1989.

[23] B. Pierce and H. Winter, "Pure vs. mixed commodity bundling," Rev. Ind. Organ., vol. 11, no. 6, pp. 811-821, 1996.

[24] R. Schmalensee, "Commodity Bundling by Single-Product Monopolies," J. Law Econ., vol. 25, no. 1 , pp. $67-71,1982$.

[25] R. E. Dansby and C. Conrad, "Commodity Bundling," AEA Pap. Proc., vol. 74, no. 2, pp. $377-$ 381, 1984.

[26] S. Martin, "Strategic and welfare implications of bundling," Econ. Lett., vol. 62, no. 3, pp. 371376, 1999.

[27] M. A. Salinger, “A Graphical Analysis of Bundling,” J. Bus., vol. 68, no. 1, p. 85, 1995.

[28] Z. . Hasibuan, "Methologi Penelitian pada Bidang Ilmu Komputer dan Teknologi Informasi. Konsep, Teknik, dan Aplikasi.," in Fakultas Ilmu Komputer Universitas Indonesia, 2007.

[29] J. F. Nunamaker, M. Chen, and T. D. M. Purdin, "Systems Development in Information Systems Research," J. Manag. Inf. Syst., vol. 7, no. 3, pp. 89-106, 1990.

[30] C. P. Putra, "Implementasi Algoritme FP-Growth untuk Market Basket Analysis dalam Menentukan Product Bundling," in Tugas Akhir. Department of Informatics Engineering. ITHB. Bandung, Indonesia, 2016. 